\title{
Spontaneous control of HIV-1 viremia in a subject with protective HLA-B plus HLA-C alleles and HLA-C associated single nucleotide polymorphisms
}

Marco Moroni ${ }^{1}$, Silvia Ghezzi ${ }^{2}$, Paolo Baroli ${ }^{3}$, Silvia Heltai ${ }^{4}$, Davide De Battista ${ }^{4}$, Simone Pensieroso ${ }^{5}$, Mariangela Cavarelli ${ }^{5}$, Stefania Dispinseri ${ }^{5}$, Irene Vanni ${ }^{6}$, Claudia Pastori $^{7}$, Pietro Zerbi ${ }^{8}$, Antonella Tosoni ${ }^{8}$, Elisa Vicenzi ${ }^{2}$, Manuela Nebuloni ${ }^{8}$, Kim Wong ${ }^{9}$, Hong Zhao ${ }^{9}$, Sarah McHugh ${ }^{9}$, Guido Poli ${ }^{10,11}$, Lucia Lopalco ${ }^{7}$, Gabriella Scarlatti ${ }^{5}$, Roberto Biassoni ${ }^{6}$, James I Mullins ${ }^{9 \dagger}$, Mauro S Malnati ${ }^{4 \dagger}$ and Massimo Alfano ${ }^{10,12^{*}+}$

\begin{abstract}
Introduction: Understanding the mechanisms by which some individuals are able to naturally control HIV-1 infection is an important goal of AIDS research. We here describe the case of an HIV- $1^{+}$woman, CASE1, who has spontaneously controlled her viremia for the last 14 of her 20 years of infection.

Methods: CASE1 has been clinically monitored since 1993. Detailed immunological, virological and histological analyses were performed on samples obtained between 2009 and 2011.

Results: As for other Elite Controllers, CASE1 is characterized by low to undetectable levels of plasma HIV-1 RNA, peripheral blood mononuclear cell (PBMC) associated HIV-1 DNA and reduced in vitro susceptibility of target cells to HIV-1 infection. Furthermore, a slow rate of virus evolution was demonstrated in spite the lack of assumption of any antiretroviral agent. CASE1 failed to transmit HIV-1 to either her sexual male partner or to her child born by vaginal delivery. Normal values and ratios of T and B cells were observed, along with normal histology of the intestinal mucosa. Attempts to isolate HIV-1 from her PBMC and gut-derived cells were unsuccessful, despite expression of normal cell surface levels of CD4, CCRC5 and CXCR4. CASE1 did not produce detectable anti-HIV neutralizing antibodies in her serum or genital mucosal fluid although she displayed potent T cell responses against HIV-1 Gag and Nef. CASE1 also possessed multiple genetic polymorphisms, including HLA alleles (B*14, B*57, $C^{*} 06$ and $C^{*} 08.02$ ) and HLA-C single nucleotide polymorphisms (SNPs, rs9264942 C/C and rs67384697 del/del), that have been previously individually associated with spontaneous control of plasma viremia, maintenance of high $\mathrm{CD}^{+} \mathrm{T}$ cell counts and delayed disease progression.

(Continued on next page)
\end{abstract}

\footnotetext{
* Correspondence: massimo.alfano@hsr.it

${ }^{\dagger}$ Equal contributors

${ }^{10}$ AIDS Immunopathogenesis Unit, Division of Immunology, Transplantation and Infectious Disease, San Raffaele Scientific Institute, Via Olgettina n. 58, Milan 20132, Italy

${ }^{12}$ Present address; Division of Experimental Oncology, Unit of Urology, URI; IRCCS Ospedale San Raffaele, Via Olgettina n. 60, Milan 20132, Italy Full list of author information is available at the end of the article
} 
(Continued from previous page)

Conclusions: CASE1 has controlled her HIV-1 viremia below the limit of detection in the absence of antiretroviral therapy for more than 14 years and has not shown any sign of immunologic deterioration or disease progression. Co-expression of multiple protective HLA alleles, HLA-C SNPs and strong T cell responses against HIV-1 proteins are the most likely explanation of this very benign case of spontaneous control of HIV-1 disease progression.

Keywords: Human Immunodeficiency Virus (HIV), Viremia, Human Leukocyte Antigen (HLA), Single Nucleotide Polymorphisms (SNPS), Elite controller (ELC), Long term nonprogressor (LTNP)

\section{Introduction}

In the absence of combination antiretroviral therapy (cART) HIV-1 infection results in AIDS and death in most individuals. In contrast, a minority of individuals demonstrate an almost absolute capacity to resist infection (e.g., carriers of CCR5- $\Delta 32$ homozygosity) [1]. Others, when infected, experience significantly delayed disease progression, either in terms of maintenance of peripheral $\mathrm{CD}^{+} \mathrm{T}$ cell counts $\geq 500$ cells/ $\mu$ l after $7-8$ years of HIV-1 infection (long-term non progressors, LTNP) or by spontaneously controlling their HIV viremia [commonly referred to as "Elite Controllers (ELC)" when $90 \%$ of plasma HIV-1 RNA values are $<50$ copies/ml, or "HIV Controllers (HIC)", when 90\% of plasma viremia measurements are $<500$ copies $/ \mathrm{ml}$ for $\geq 12$ months]. Rare ( $<1 \%$ of all infected individuals) cases show both LTNP and EC features and have been defined as "elite LTNP" [2,3].

Among other correlates of delayed HIV-1 progression in the absence of cART the role of several alleles of Human Leukocyte Antigen (HLA) Class I genes, such as HLA-B*27 [4] and HLA-B*57 [5] has been well established. Additional associations between MHC-Class I and III SNPs and the LTNP phenotype have been observed [6].

Thus, CASE1 detailed immunologic, virological and genetic profile may provide clues to the design of therapeutic vaccines aiming at achieving a functional cure of HIV-1 infection in the absence of ART [7].

\section{Methods}

\section{IRB approval}

Biological samples were collected after receiving formal written waiver from the institutional review board (protocol MUCIM approved in January 2007 by the Ethics Committee Ospedale San Raffaele, Milan, Italy), and signed written informed consent.

\section{HIV-1 RNA and DNA quantitation}

HIV-1 plasma RNA was measured using the Amplicor Monitor (Roche) assay (dynamic range: 50-750,000 copies/mL), and HIV-1 DNA quantification was performed using an in-house real-time PCR assay, as described [8].
Viral genetic analysis

Isolation of plasma HIV RNA and PBMC-associated HIV DNA, reverse transcription, amplification, gag and env sequencing were performed according to the published methods reported in the Additional file 1 section.

\section{MiR-148a/b binding site (single nucleotide}

polymorphisms, SNP: rs67384697) and -35Kb 5'UTR HLA-C (SNP: rs9264942) analysis

Genomic DNA was extracted from CASE1's PBMC using the PureLink Genomic DNA kit (Invitrogen, Carlsbad, CA), and a pyrosequencing approach was used to determine SNPs. Detailed methods are reported in the Additional file 1 section.

\section{Culture and co-culture of rectal biopsy with allogeneic T cell blasts}

Histocultures of intestinal biopsies were performed as previously reported [9]; both cells and histoculture supernatants were collected $24 \mathrm{~h}$ later. Cells were dispersed by enzymatic digestion with collagenase IV $(0.5 \mathrm{mg} / \mathrm{ml}$ in complete culture medium, $30 \mathrm{~min}$ at $37^{\circ} \mathrm{C}$ ), passed through a $22 \mathrm{G}$ needle and filtered with a $70 \mu \mathrm{m}$ cell strainer. The digestion was repeated and cells from the two rounds were pooled and debris removed by centrifugation. Two million biopsy-derived cells were cultivated either alone or with 2x10 [6] PHA-stimulated PBMC from two different donors that had been previously depleted or not of $\mathrm{CD}^{+} \mathrm{T}$ cells by magnetic immunobeads. Both cultures and co-cultures were maintained for 30 days in IL-2 enriched medium, collecting their supernatants every 3 days for measurement of virus using either $\mathrm{Mg}^{++}$-dependent reverse transcriptase (RT) activity [10] or HIV-1 p24 Gag antigen by ELISA.

HIV-1 isolation from and ex-vivo infection of CASE1 PBMC Three independent attempts were made to isolate HIV-1 from peripheral $\mathrm{CD}^{+} \mathrm{T}$ cells according to published protocols [11]. Supernatants were collected every 3-4 days for up to 4 weeks of cultivation and tested for the presence of either $\mathrm{Mg}^{++}$-dependent reverse transcriptase (RT) activity or HIV-1 p24 Gag antigen by ELISA.

For ex-vivo infection, $\mathrm{CD}^{+}$leukocytes from both CASE1 and her partner were isolated by negative selection from peripheral blood by Ficoll-Hypaque, washed 
and suspended in complete medium and purified as described above. Cells were stimulated with PHA and 3 days later washed and infected with CCR5-dependent (R5) HIV-1 $1_{\mathrm{BaL}}$ or CXCR4-dependent (X4) HIV-1 $1_{\mathrm{LAI} / \mathrm{III}}$ at a multiplicity of infection of 0.2. Culture supernatants were collected every 3-4 days for up to 4 weeks and tested for the presence of RT activity.

\section{ELISpot assay for IFN- $\gamma$ Peptides}

The Variable Overlapping Peptide Scanning Design (VOPSD) technique [12] was used to design peptides derived from HIV-1 encoded antigens Tat (11 peptides, Repository number: ARP7103.1-11), Nef (30 peptides, Repository number: ARP7102.1-30) and Gag (84 peptides, Repository number: ARP7114.1-84) kindly provided by the Centre for AIDS Reagents, National Institute for Biological Standards and Control (NIBSC HPA UK). Single peptides or peptide pools were used to stimulate PBMC collected in November 2009 and June 2011 at a final concentration of $2 \mu \mathrm{M}$. Validation of the VOPSD strategy was obtained by direct comparison with 15 mer or 20 mer peptide sets, as recently reported [12]. ELISpot for IFN- $\gamma$ was performed as previously described [13], and detailed methods reported in the Additional file 1 section.

\section{Intracellular cytokine staining}

Thawed PBMC ( $\geq 80 \%$ viable) were plated in a 96-well plate after $4 \mathrm{~h}$ of resting (EuroClone) at a concentration of 1x10 [6] PBMC/well in complete RPMI medium [10\% FBS (Lonza-BioWhittaker) in RPMI (Lonza-BioWhittaker)] with single/pools of HIV-1 derived peptides $(2 \mu \mathrm{M})$ in the presence of a mixture of co-stimulatory anti-CD28 and anti-CD49d Ab (1.3 $\mu \mathrm{g} / \mathrm{ml}$ each, Becton Dickinson). Cells were then treated and stained as previously described [13]. Detailed methods are reported in the Additional file 1 section.

\section{Results}

\section{Clinical history}

A previous female intravenous-drug user, (CASE1), was diagnosed with HIV-1 infection in 1993 (age: 23 years old) in the course of a pregnancy screening test; she was confirmed to be $\mathrm{HIV}-1^{+}$in the following years. CASE1 was repeatedly found seropositive for anti-HIV-1 antibodies (Ab), but negative for anti-HIV-2 Ab. Her viremia levels were undetectable when assessed for the first time in May 1997, but 1,900 copies of HIV-1 RNA/ml were demonstrated in Nov 1997 that dropped to 200 copies/ $\mathrm{ml}$ in Aug 1999. Since then, HIV-1 viremia levels, that were monitored at least twice a year, have remained $<50$ copies/ml although CASE1 never assumed any antiretroviral agent. She also never reported clinical episodes suggestive of immunodeficiency, while her peripheral $\mathrm{CD}_{4}^{+}$ and $\mathrm{CD}^{+} \mathrm{T}$ cell counts have remained in the normal range of uninfected healthy individuals through all these years (Figure 1A).

CASE1 reported $>20$ years of unprotected sexual intercourse with her male partner, who remained HIV-1 seronegative. She also had a child born in 1994 by vaginal delivery who has remained uninfected.

In 1997 CASE1 was diagnosed with hepatitis $C$ virus ( $\mathrm{HCV}$, genotype $3 \mathrm{a}$ ) infection, becoming negative for $\mathrm{HCV}$ viremia with normal levels of transaminases in 2005 after therapy with Pegylated Interferon plus Rebetol (Additional file 1: Figure S1).

\section{Virological determinations and ex vivo infection of CASE1 $\mathrm{CD}^{+} \mathrm{T}$ cells}

In June 2009 colon biopsies were taken for diagnostic purposes. Hematoxylin-eosin, Giemsa, PAS staining and transmission electron microscopy revealed normal histology of the intestinal mucosa, lack of inflammatory infiltrates, microbes, virions or cell injury (Additional file 1: Figure S2). The tissue was also negative for the presence of HIV-1 p24 Gag cells by immunohistochemistry, although its viral DNA content was estimated to be 881 copies $/ 10^{6}$ cells. In vitro cultivation of either 6 colon biopsy histocultures or of colon-derived leukocytes ( $2 \times 10^{6}$ cells) co-cultivated with CD8-depleted $\mathrm{T}$ cell blasts of two seronegative donors were negative for virus replication in terms of either RT activity or p24 Gag production (data not shown). Furthermore, neither allogeneic cultivation of $5 \times 10^{5}$ PBMC-purified CD4 ${ }^{+}$cells from CASE1 with $\mathrm{T}$ cell blasts of two seronegative donors, nor direct cultivation of the same number of CASE1 cells in medium containing IL-2, induced virus replication (data not shown).

Ex vivo infection of CASE1 $\mathrm{CD}^{+} \mathrm{T}$ cell blasts with HIV-1 $\mathrm{R} 5_{\mathrm{BaL}}$ or $\mathrm{X} 4_{\mathrm{LAI} / \mathrm{IIIB}}$ strains resulted in virus replication, although at lower levels compared to those observed after infection of $\mathrm{CD}^{+}{ }^{+} \mathrm{T}$ cell blasts from her partner (Figure 1B and $\mathrm{C}$ ).

\section{Sequence analysis of CASE 1 HIV-1 DNA}

Quantitative PCR from CASE1 plasma samples were repeatedly $<50$ copies HIV-1 RNA/ml (Figure 1A), and only 2 viral genomes were detected in a total of $9 \mathrm{~mL}$ of plasma from June and Nov 2009 by multiplex PCR to amplify both full length gag and gp120 env coding sequences (see Additional file 1). Her PBMC-associated HIV-1 DNA load in June, and Nov 2009 and in June 2011 was $28,<13$ and 10 copies $/ 10^{6}$ cells, respectively. In the same dates, 23 gag- and 20 gp120 env-sequences (all with open reading frames) were obtained from a total of $21 \times 10^{6} \mathrm{PBMC}$.

All 15 PBMC-derived single genome HIV-1 gag coding sequences from June $(\mathrm{N}=6)$ and $\operatorname{Nov}(\mathrm{N}=9) 2009$ were 

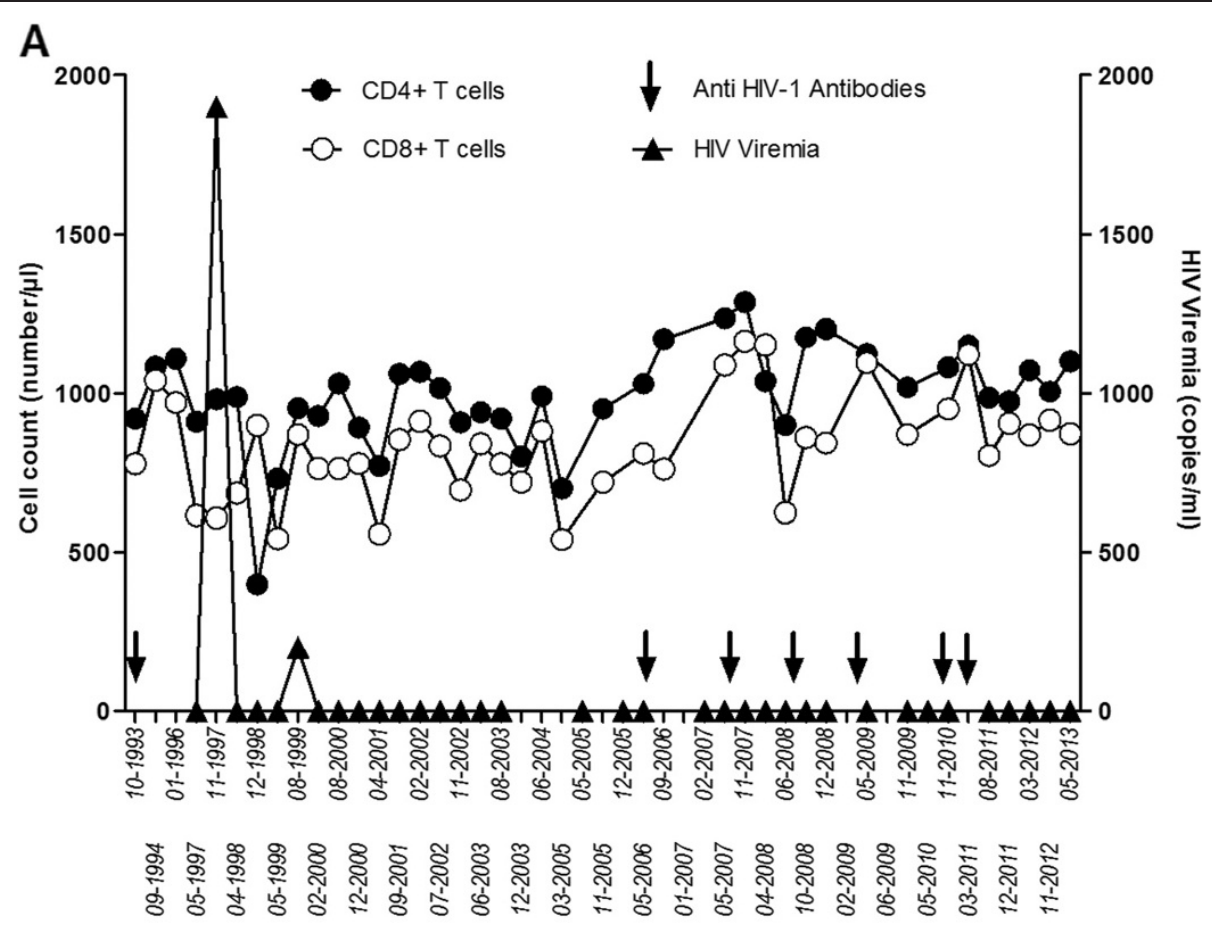

B

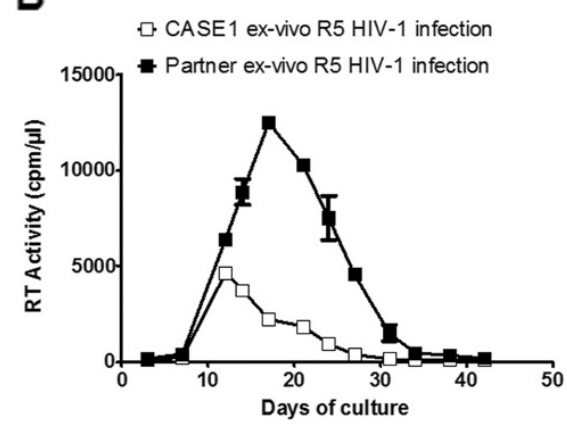

C

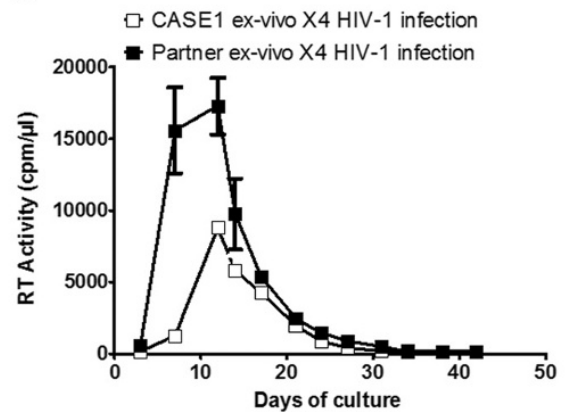

Figure 1 CASE1's natural control of HIV-1 viremia. (A) Levels of peripheral CD4 $4^{+}$and $C D 8^{+} T$ cells, plasma viral RNA and the presence of anti-HIV-1 Ab in CASE1 plasma were monitored over 20 years of infection. Purified peripheral CD4 ${ }^{+}$cells were isolated from CASE1 and infected with either an R5 (B) or an X4 (C) strain, resulting in detectable virus replication. Purified CD4 ${ }^{+} \mathrm{T}$ cells of her sexual partner supported higher levels of virus replication. Bars indicate error of the mean from duplicate cultures.

identical, as were 5 out of 8 sequences from June 2011 (Figure 2A). In the case of env (Figure 2B), all 4 PBMC sequences from June 2009 were identical; all 10 sequences from Nov 2009 encoded identical proteins (4 sequences had the same synonymous site mutation) and differed from the June 2009 population at only one amino acid. Three out of 6 env sequences from June 2011 were identical to the major Nov 2009 population and 2 out of 6 were identical to the minor Nov 2009 population. One env sequence and gag sequences from 3 June 2011 were subtle outliers, with an additional 5 or $5-17$ changes, respectively, relative to the major virus populations (Figure 2). Despite this exceptional overall homogeneity in cell-associated viral DNA (Mean sequence diversity across all 3 time points $=0.17 \%$ in $\mathrm{gag}$ and $0.08 \%$ in env), the single gag and env sequences obtained from the Nov 2009 plasma sample were significantly divergent from the PBMC-associated DNA sequences (Mean $=1.1 \%$ in $\mathrm{gag}$ and $2.5 \%$ in env), although they each shared some of the mutations that distinguished the PBMC outlier sequences from Nov2011. The changes in gag shared with each of the outlier PBMC led to the reversion of the B*57-associated AA substitution I147L in the immunodominant [14] B*57 epitope IW9, restoring the optimal CTL epitope sequence, and to the introduction of the T242N substitution in the TW10 epitope (Figure 2A), normally associated with CTL escape. No mutations were observed in the B*57-restricted epitopes KF11 or 


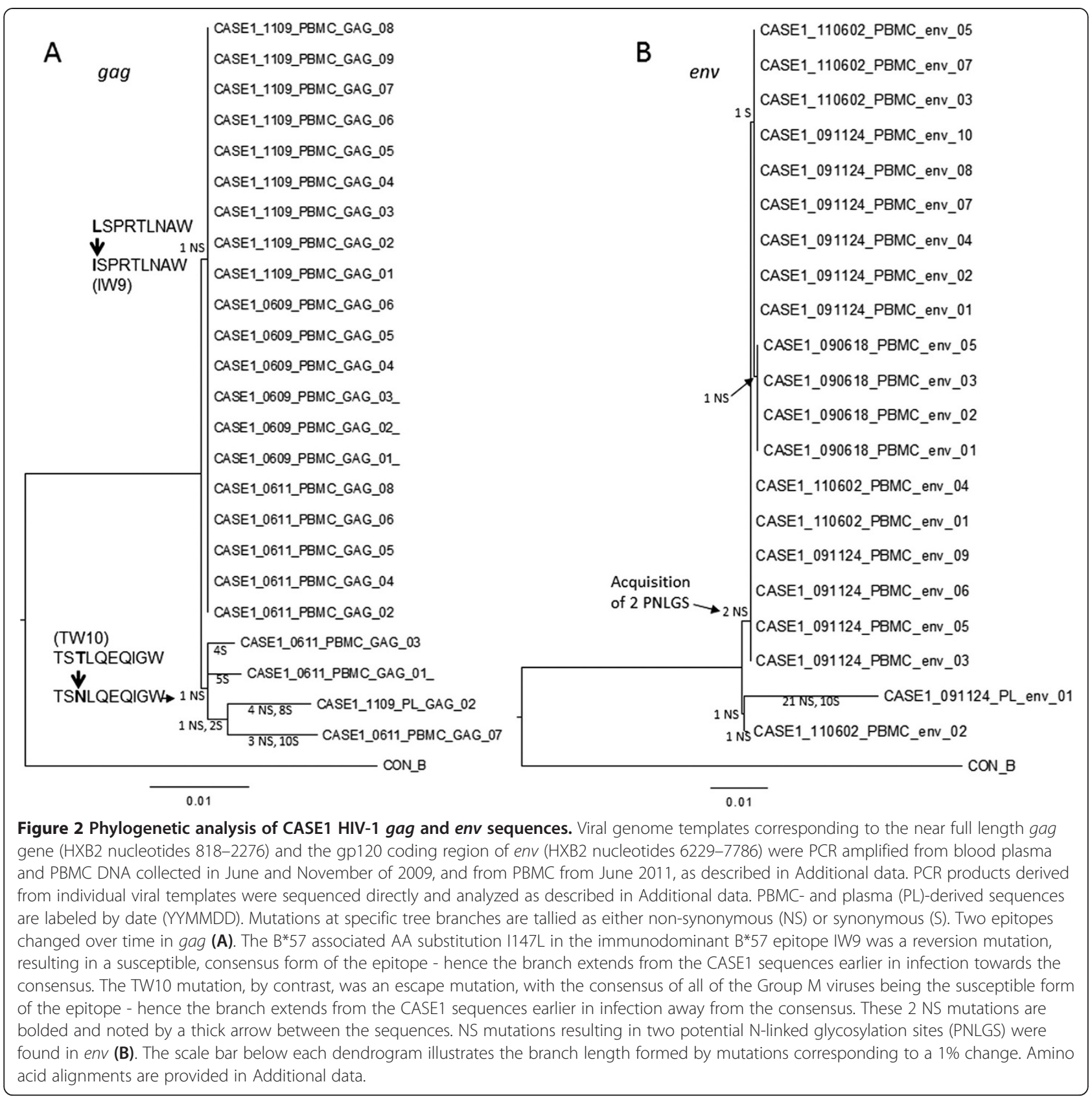

the B*14 epitope DA9 (Additional file 1: Figure S3A). Finally, 2 of the 3 shared non-synonymous site changes in env corresponded to acquisition of potential N-linked glycosylation sites (Figure 2B).

\section{CASE1 protective alleles}

Although not carrying the protective alleles CCR5- $\triangle 32$ and CCR2-64I, CASE1 does express HLA B and C alleles ( $B * 14.02$ and $B * 57.08$; $C * 06$ and $C * 08.02$ ), previously associated, either alone $[5,15]$ or in combination $[16,17]$, with slow/non-progression in LTNP and low levels of viremia in the absence of cART assumption.
In addition, $\mathrm{CASE} 1$ possesses the $\mathrm{C} / \mathrm{C}$ genotype in the rs9264942 (C/T) -35 SNP and the del/del polymorphism (rs67384697 G/deletion) mapping upstream to the 5' and within the $3^{\prime}$ untranslated region of the HLA-C gene, respectively. These 2 SNPs have been reported to be in strong linkage dysequilibrium being associated with control of HIV-1 viremia [5,6].

\section{Immunological phenotypes and immune responses}

CASE1 and her partner were found to have a distribution of B lymphocyte subpopulations comparable to those of uninfected individuals (Additional file 1: Table S1). Two 


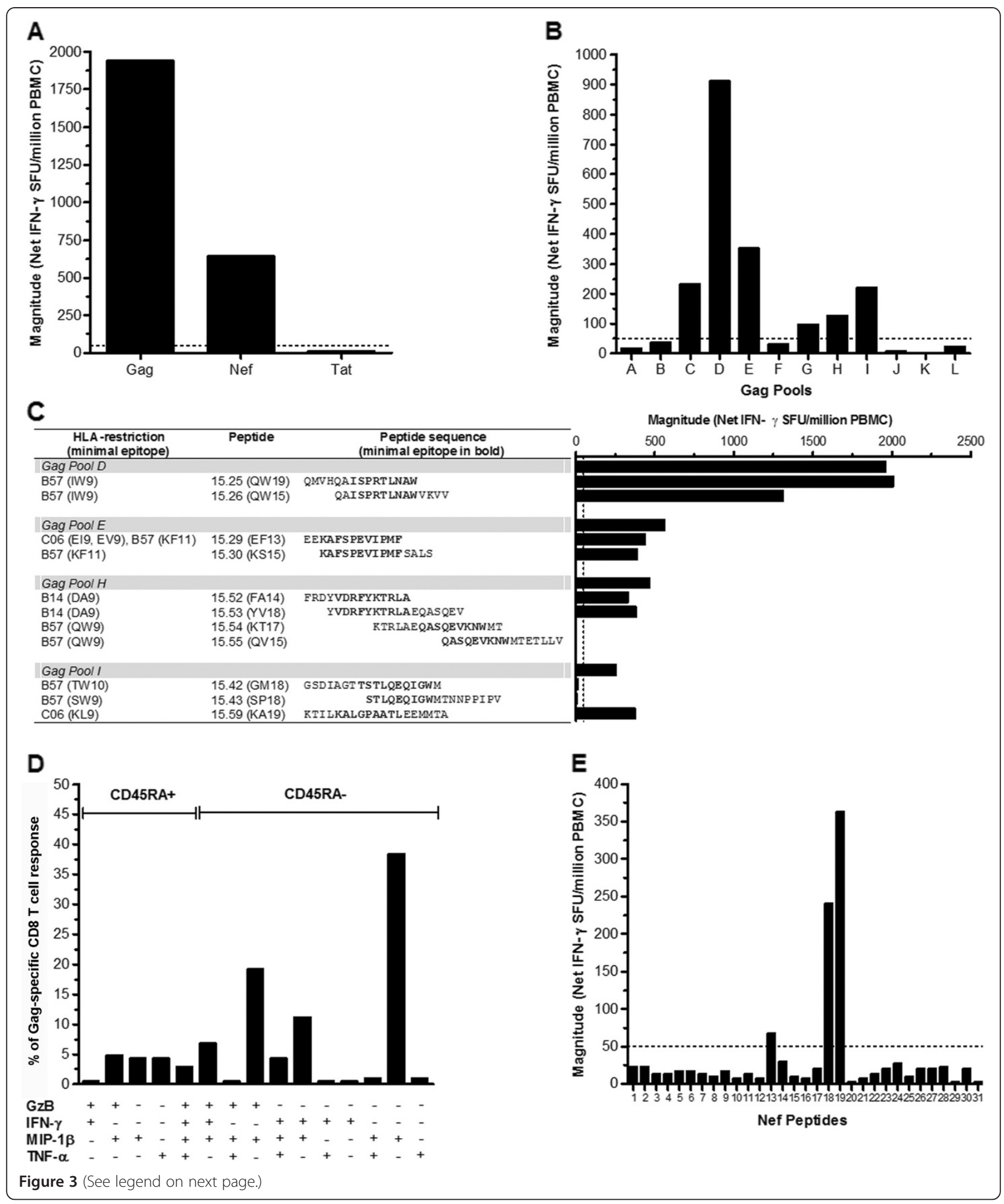


(See figure on previous page.)

Figure 3 T-cell responses of CASE1 T cells to Gag, Nef, and Tat peptides. (A) Recognition of Gag and Nef, but not of Tat peptide pools by CASE1 PBMC collected in June 2011. (B) Recognition of Gag pools (A-L): pools D, E, G, H, and I contain well-defined HLA-B*57 restricted Gag epitopes. (C) Identification of epitopes recognized by CASE1 contained in Gag pools D, E, H and I. The table provides the HLA-restriction, the peptide designation and its sequence. The sequence of minimal epitopes for both Gag and Nef are shown in bold. (D) PBMC isolated from CASE1 were either left unstimulated or were stimulated with Gag peptide \#25 and \#26 and functionality of CD8+ T assessed by means of cytofluorimetric analysis for the production of Granzyme-B (GzB), Interferon- $\gamma$ (IFN- $\gamma)$, CC chemokine ligand 4 (CCL4)/Macrophage Inflammatory Protein-1 $\beta$ (MIP-1 $\beta$ ) and Tumor Necrosis Factor-a (TNF-a); the cell population was subdivided into the CD45RA ${ }^{+}$and $C D 45 R A^{\text {neg }} C D 8^{+} T_{-c e l l}$ subsets and the percentages of these subsets were calculated relative to the peptide 25 and 26 Gag-specific response. (E) Recognition of Nef overlapping peptides. The HLA-B*57 and C*06 restricted minimal epitopes contained in Nef \#13 (RPMTYKAAVDLSHFLK) were: RPMTYKAAV ( $\left.C^{*} 06\right)$, MTYKAAVDL $\left(C^{*} 06\right)$, KAAVDLSHF (B*57), AAVDLSHFL (C*06); minimal epitopes in Nef \#18 (LDLWIYHTQGYFPDWQNY) and Nef \#19 (YHTQGYFPDWQNYT) were: HTQGYFPDW (B*57) and GYFPDWQNY (C*06). The dotted line indicates the negative cut-off of the assay.

serum samples (tested as total and purified immunoglobulins) and cervico-vaginal derived $\mathrm{Ab}$ collected in June 2009 and Nov 2009 did not show neutralizing activity against a panel of different HIV clades and phenotypes (Additional file 1: Table S2). CASE1 and her partner also had a normal distribution of $\mathrm{T}$ cell subpopulations (Additional file 1: Table S3), and both expressed comparable levels of CXCR4 and CCR5 on CD4 ${ }^{+}$lymphocytes (Additional file 1: Figure S4).

The breadth and magnitude of T-cell responses were assessed using CASE1 PBMC collected in Nov 2009 and June 2011. T cell responses were observed against Gag and Nef but not against Tat peptides (Figure 3A). Recognition of Gag peptide pools was mainly directed against regions containing well-defined HLA-B*57-restricted Gag epitopes (pools D, E, G, H and I, Figure 3B), without appreciable differences between the two dates.

Among the peptides present in Gag pools D and E, those expressing HLA-B*57 restricted epitopes (I/LW9 peptides 25 and 26 from pool D; KF11 peptide 29 and 30 pool E) mounted the strongest T-cell response (Figure $3 \mathrm{C}$ ) as reported for LTNP [18]. Interestingly, recognition of the B*14-restricted epitope DA9, previously associated with virological control [19], was also observed (peptides 52 and 53 from pool $\mathrm{H}$ ), whereas recognition of the B57* restricted epitope QW9 (peptide 54 and 55) was absent (Figure 3C). Moreover, recognition of pool I was not directed against the $B^{*} 57$-restricted epitope TW10 (peptides 42 and 43), but toward the C*06 restricted epitope KL9 (peptide 59, Figure 3C).

Among $\mathrm{CD}^{+} \mathrm{T}$ cells specific for HLA-B*57 (I/L)W9 restricted Gag epitopes (peptides 25 and 26), 34.6\% expressed CCL4/MIP-1 $\beta$ and $50.5 \%$ were polyfunctional (Figure 3D). Recognition of Nef peptide pools was also mainly directed against regions containing well-defined HLA-B*57 and C*06 restricted Nef epitopes (Figure 3E).

\section{Conclusions}

We here report that a woman (CASE1), who has been infected with HIV-1 for at least 20 years, has remained in good health with features of both EC and LTNP for the last 14 years. CASE1 co-expresses HLA-B ("14 and *57) alleles and HLA-B-mediated immune responses, together with HLA-C alleles (*06 and *08.02) associated with SNPs rs9264942C/C and rs67384697G/deletion and HLA-C restricted immune responses as her most evident features compatible with strong and durable control of HIV-1 infection and disease progression.

Although CASE1's CD4 ${ }^{+}$T cells were infectable in vitro by both $\mathrm{R} 5$ and $\mathrm{X} 4 \mathrm{HIV}-1$ strains, they showed lower levels of virus replication in comparison to those of the seronegative partner, suggesting the presence of restriction factors, such as p21 [20], limiting the virus replicative capacity in vitro and perhaps accounting for the lack of virus replication observed both in vivo and upon ex vivo cultivation of CASE1's PBMC and gut-associated leukocytes.

Cell-associated HIV-1 DNA was detectable in PBMC and gut-mucosa derived cells at very low levels while gag sequences from single copy plasma RNA molecules and PBMC-associated HIV-1 DNA revealed the late emergence of mutations in two immunodominant HLA-B*57restricted Gag epitopes co-existing on the same sequences. The mutation T242N observed in the TW10 epitope typically emerges early in infection and is known to effect CTL escape and impair viral fitness. However, this mutation is has not been associated with the EC status, being more frequently detected in $\mathrm{B}^{*} 57^{+} \mathrm{HIV}-1$ progressors [21]. The second mutation emerged in the I/LW9 $\mathrm{B} * 57$ associated epitope, restoring the original IW9 epitope with little or no impact on viral escape or fitness reported in prior studies. This behavior is reminiscent of EC who have extremely low levels of viral RNA in plasma, significant differences between contemporary viruses in the plasma and $\mathrm{PBMC}$, and a high frequency of synonymous mutations in the plasma virus [22-25]. It is also noteworthy that HLA$B * 57$ epitope variation emerged in plasma-associated virus at the same sampling times of acquisition of two potential $\mathrm{N}$-linked glycosylation sites in Env, including one that was previously implicated in the evasion of $\mathrm{Ab}$ neutralization [26]. These viral features, together with the persistence of CD8-mediated $T$ cell responses, suggest the persistence of extremely low levels of virus replication in CASE1. The 
acquisition of several important amino acid substitutions in plasma-associated virus and in PBMC, in 2009 and 2011, respectively, suggests that her virological control may be waning.

In addition, CASE1 carries a unique combination of HLA-B protective alleles associated with $\mathrm{CD}^{+}$T cellmediated control of HIV-1 replication and strong $\mathrm{CD} 8^{+}$ T cells polyfunctional responses against HLA-B" 57 and B*14-restricted Gag epitopes, as also observed in ELC and LTNP [27] that may account for the lack of $\mathrm{CD}^{+} \mathrm{T}$ cell depletion in peripheral blood and gut [28]. The higher levels of expression of HLA-C alleles carrying a deleted $\mathrm{miR}-148 \mathrm{a} / \mathrm{b}$ binding site vs. those without a deleted site might facilitate greater T-cell recognition of infected cells [29]. In support of this interpretation CASE1 was also characterized by the presence of long lasting C*06-restricted T-cell responses against Nef epitopes.

HLA molecules play a central role in the control of HIV disease progression [17]. In this regard, CASE1 has multiple HLA features that were previously individually associated with control of HIV-1 viremia, including HLA class I alleles (HLA-B*057 and *014, HLA-C*06 and "0802) and two SNPs within the HLA-C locus (rs9264942C/C, and $263 \mathrm{del} / \mathrm{del}, 259 \mathrm{~T} / \mathrm{T}, 261 \mathrm{C} / \mathrm{C}$, $266 \mathrm{~T} / \mathrm{T}$ on rs67384697). Thus, co-expression of protective HLA-B and HLA-C alleles as well as of HLA-C SNPs, and the associated T cell immune responses, some of which polyfunctional [30], likely provide the strong and durable control of HIV-1 replication and disease progression in CASE1.

\section{Additional file}

Additional file 1: Table S1. Titer of anti-HIV neutralizing Ab in CASE1 serum and mucosal-derived fluid. Table S2. Percentage of B lymphocyte phenotypes in CASE1, her partner, other Elite controllers and HIV-1 negative controls. Table S3. Peripheral T lymphocyte phenotype distribution (\%) in CASE1 and her partner. Figure S1. CASE1's HCV related clinical features. Figure S2. CASE1's intestinal mucosa histological and ultrastructural analysis. Figure S3. Amino acid alignments of CASE1 Gag (A) and Env-gp120 (B) proteins. Figure S4. CXCR4 and CCR5 expression by CASE1's and partner's peripheral blood $\mathrm{CD}^{+} \mathrm{T}$ cells.

\section{Competing interests}

All authors declare that they have no competing interests.

\section{Authors' contributions}

All authors contributed to conception and design of the study, acquisition and analysis of data. All authors contributed in drafting and revising the manuscript, and approved the final version.

\section{Authors' information}

${ }^{\dagger}$ James I Mullins, Mauro S Malnati and Massimo Alfano were co-last authors.

\section{Acknowledgments}

All authors would like to acknowledge the subject coded as CASE1 for her repeated willingness to provide biological samples.

This work was supported by the EUROPRISE-Network of Excellence (grant number LSHP CT-2006-037611 funded by EC under the Sixth Framework Programme), the NGIN consortium (grant number 201433 and the Combined
Highly Active Anti-Retroviral Microbicides (CHAARM) grant 242135 funded by EC under the Seventh Framework Programme, the Italian Ministry of Health (grants $40 \mathrm{H} 16$ and $40 \mathrm{H} 23$ ), the Bill and Melinda Gates Foundation GHRC-CAVD Project, NIH grants to JIM (Al47734) and the Bioinformatics Core of the University of Washington Centers for AIDS Research (NIH Al27757). We thank the NIBSC-CFAR (UK) for providing viruses and monoclonal antibodies.

\section{Author details}

${ }^{1}$ Infectious Disease Unit, Busto Arsizio Public Hospital, P.le Solaro n. 3, Busto Arsizio 21052Varese, Italy. ${ }^{2}$ Viral Pathogens and Biosafety Unit, Division of Immunology, Transplantation and Infectious Disease, San Raffaele Scientific Institute, Milan, Italy. ${ }^{3}$ Service Lab Fleming Research, Busto Arsizio, Varese, Italy. ${ }^{4}$ Human Virology Unit, Division of Immunology, Transplantation and Infectious Disease, San Raffaele Scientific Institute, Milan, Italy. ${ }^{5}$ Viral Evolution and Transmission Unit, Division of Immunology, Transplantation and Infectious Disease, San Raffaele Scientific Institute, Milan, Italy. ${ }^{6}$ Department of Translational Research, Istituto Giannina Gaslini, Genoa, Italy. ${ }^{7}$ Immunobiology of HIV Unit, Division of Immunology, Transplantation and Infectious Disease, San Raffaele Scientific Institute, Milan, Italy. ${ }^{8}$ Pathology Unit, Luigi Sacco Hospital, Department of Biomedical and Clinical Sciences, University of Milan, Milan, Italy. ${ }^{9}$ Departments of Microbiology, Medicine and Laboratory Medicine, University of Washington, Seattle, WA, USA. ${ }^{10}$ AIDS Immunopathogenesis Unit, Division of Immunology, Transplantation and Infectious Disease, San Raffaele Scientific Institute, Via Olgettina n. 58, Milan 20132, Italy. ${ }^{11}$ School of Medicine, Vita-Salute San Raffaele University, Milan, Italy. ${ }^{12}$ Present address; Division of Experimental Oncology, Unit of Urology, URI; IRCCS Ospedale San Raffaele, Via Olgettina n. 60, Milan 20132, Italy.

Received: 16 August 2014 Accepted: 20 November 2014

Published online: 05 December 2014

\section{References}

1. Liu H, Hwangbo Y, Holte S, Lee J, Wang C, Kaupp N, Zhu H, Celum C, Corey L, McElrath MJ, Zhu T: Analysis of genetic polymorphisms in CCR5, CCR2, stromal cell-derived factor-1, RANTES, and dendritic cell-specific intercellular adhesion molecule-3-grabbing nonintegrin in seronegative individuals repeatedly exposed to HIV-1. J Infect Dis 2004, 190:1055-1058.

2. Grabar $\mathrm{S}$, Selinger-Leneman $H$, Abgrall $S$, Pialoux $G$, Weiss L, Costagliola D: Prevalence and comparative characteristics of long-term nonprogressors and HIV controller patients in the French Hospital Database on HIV. AIDS 2009, 23:1163-1169.

3. Genovese L, Nebuloni M, Alfano M: Cell-mediated immunity in elite controllers naturally controlling HIV viral load. Front Immunol 2013, 4:86.

4. Almeida JR, Price DA, Papagno L, Arkoub ZA, Sauce D, Bornstein E, Asher TE, Samri A, Schnuriger A, Theodorou I, Costagliola D, Rouzioux C, Agut H, Marcelin AG, Douek D, Autran B, Appay V: Superior control of HIV-1 replication by CD8+ T cells is reflected by their avidity, polyfunctionality, and clonal turnover. J Exp Med 2007, 204:2473-2485.

5. Fellay J, Shianna KV, Ge D, Colombo S, Ledergerber B, Weale M, Zhang K, Gumbs C, Castagna A, Cossarizza A, Cozzi-Lepri A, De Luca A, Easterbrook P, Francioli P, Mallal S, Martinez-Picado J, Miro JM, Obel N, Smith JP, Wyniger J, Descombes P, Antonarakis SE, Letvin NL, McMichael AJ, Haynes BF, Telenti A, Goldstein DB: A whole-genome association study of major determinants for host control of HIV-1. Science 2007, 317:944-947.

6. Guergnon J, Dalmasso C, Broet P, Meyer L, Westrop SJ, Imami N, Vicenzi E, Morsica G, Tinelli M, Zanone Poma B, Goujard C, Potard V, Gotch FM, Casoli C, Cossarizza A, Macciardi F, Debre P, Delfraissy JF, Galli M, Autran B, Costagliola D, Poli G, Theodorou I, Riva A: Single-nucleotide polymorphism-defined class I and class III major histocompatibility complex genetic subregions contribute to natural long-term nonprogression in HIV infection. J Infect Dis 2012, 205:718-724.

7. Deeks SG, Autran B, Berkhout B, Benkirane M, Cairns S, Chomont N, Chun TW, Churchill M, Di Mascio M, Katlama C, Lafeuillade A, Landay A, Lederman M, Lewin SR, Maldarelli F, Margolis D, Markowitz M, Martinez-Picado J, Mullins Jl, Mellors J, Moreno S, O'Doherty U, Palmer S, Penicaud MC, Peterlin M, Poli G, Routy JP, Rouzioux C, Silvestri G, Stevenson M, et al: Towards an HIV cure: a global scientific strategy. Nat Rev Immuno/ 2012, 12:607-614.

8. Malnati MS, Scarlatti G, Gatto F, Salvatori F, Cassina G, Rutigliano T, Volpi R, Lusso P: A universal real-time PCR assay for the quantification of group-M HIV-1 proviral load. Nat Protoc 2008, 3:1240-1248. 
9. Grivel JC, Elliott J, Lisco A, Biancotto A, Condack C, Shattock RJ, McGowan I, Margolis L, Anton P: HIV-1 pathogenesis differs in rectosigmoid and tonsillar tissues infected ex vivo with CCR5- and CXCR4-tropic HIV-1. Aids 2007, 21:1263-1272.

10. Nebuloni M, Zawada L, Ferri A, Tosoni A, Zerbi P, Resnati M, Poli G, Genovese L, Alfano M: HIV-1 infected lymphoid organs upregulate expression and release of the cleaved form of UPAR that modulates chemotaxis and virus expression. PLoS One 2013, 8:e70606.

11. Ghezzi S, Pacciarini F, Nozza S, Racca S, Mariani S, Vicenzi E, Lazzarin A, Veglia F, Tambussi G, Poli G: Persistence of CCR5 usage among primary human immunodeficiency virus isolates of individuals receiving intermittent interleukin-2. HIV Med 2010, 11:349-352.

12. Malnati MS, Heltai S, Cosma A, Reitmeir P, Allgayer S, Glashoff RH, Liebrich W, Vardas E, Imami N, Westrop S, Nozza S, Tambussi G, Butto S, Fanales-Belasio E, Ensoli B, Ensoli F, Tripiciano A, Fortis C, Lusso P, Poli G, Erfle V, Holmes H: A new antigen scanning strategy for monitoring HIV-1 specific T-cell immune responses. J Immunol Methods 2012, 375:46-56.

13. Kutscher S, Dembek CJ, Allgayer S, Heltai S, Stadlbauer B, Biswas P, Nozza S, Tambussi G, Bogner JR, Stellbrink HJ, Goebel FD, Lusso P, Tinelli M, Poli G, Erfle V, Pohla H, Malnati M, Cosma A: The intracellular detection of MIP-1beta enhances the capacity to detect IFN-gamma mediated HIV-1-specific CD8 T-cell responses in a flow cytometric setting providing a sensitive alternative to the ELISPOT. AIDS Res Ther 2008, 5:22.

14. Altfeld M, Addo MM, Rosenberg ES, Hecht FM, Lee PK, Vogel M, Yu XG, Draenert R, Johnston MN, Strick D, Allen TM, Feeney ME, Kahn JO, Sekaly RP, Levy JA, Rockstroh JK, Goulder PJ, Walker BD: Influence of HLA-B57 on clinical presentation and viral control during acute HIV-1 infection. AIDS 2003, 17:2581-2591.

15. Okulicz JF, Lambotte O: Epidemiology and clinical characteristics of elite controllers. Curr Opin HIV AIDS 2011, 6:163-168.

16. Lazaryan A, Song W, Lobashevsky E, Tang J, Shrestha S, Zhang K, McNicholl JM, Gardner LI, Wilson CM, Klein RS, Rompalo A, Mayer K, Sobel J, Kaslow RA: The influence of human leukocyte antigen class I alleles and their population frequencies on human immunodeficiency virus type 1 control among African Americans. Hum Immunol 2011, 72:312-318.

17. Pereyra F, Jia X, McLaren PJ, Telenti A, de Bakker PI, Walker BD, Ripke S, Brumme CJ, Pulit SL, Carrington M, Kadie CM, Carlson JM, Heckerman D, Graham RR, Plenge RM, Deeks SG, Gianniny L, Crawford G, Sullivan J, Gonzalez E, Davies L, Camargo A, Moore JM, Beattie N, Gupta S, Crenshaw A, Burtt NP, Guiducci C, Gupta N, Gao X, et al: The major genetic determinants of HIV-1 control affect HLA class I peptide presentation. Science 2010, 330:1551-1557.

18. Migueles SA, Sabbaghian MS, Shupert WL, Bettinotti MP, Marincola FM, Martino L, Hallahan CW, Selig SM, Schwartz D, Sullivan J, Connors M: $\mathrm{HLA} B^{*} 5701$ is highly associated with restriction of virus replication in a subgroup of HIV-infected long term nonprogressors. Proc Natl Acad Sci U S A 2000, 97:2709-2714.

19. Mothe B, Llano A, Ibarrondo J, Zamarreno J, Schiaulini M, Miranda C, Ruiz-Riol M, Berger CT, Herrero MJ, Palou E, Plana M, Rolland M, Khatri A, Heckerman D, Pereyra F, Walker BD, Weiner D, Paredes R, Clotet B, Felber BK, Pavlakis GN, Mullins Jl, Brander C: CTL responses of high functional avidity and broad variant cross-reactivity are associated with HIV control. PLoS One 2012, 7:e29717.

20. Saez-Cirion A, Hamimi C, Bergamaschi A, David A, Versmisse P, Melard A Boufassa F, Barre-Sinoussi F, Lambotte O, Rouzioux C, Pancino G: Restriction of HIV-1 replication in macrophages and CD4+ T cells from HIV controllers. Blood 2011, 118:955-964.

21. Miura T, Brumme ZL, Brockman MA, Rosato P, Sela J, Brumme CJ, Pereyra F, Kaufmann DE, Trocha A, Block BL, Daar ES, Connick E, Jessen H, Kelleher AD, Rosenberg E, Markowitz M, Schafer K, Vaida F, Iwamoto A, Little S, Walker BD: Impaired replication capacity of acute/early viruses in persons who become HIV controllers. J Virol 2010, 84:7581-7591.

22. Migueles SA, Laborico AC, Imamichi H, Shupert WL, Royce C, McLaughlin M, Ehler L, Metcalf J, Liu S, Hallahan CW, Connors M: The differential ability of HLA B*5701+ long-term nonprogressors and progressors to restrict human immunodeficiency virus replication is not caused by loss of recognition of autologous viral gag sequences. J Virol 2003, 77:6889-6898.

23. Bailey JR, Sedaghat AR, Kieffer T, Brennan T, Lee PK, Wind-Rotolo M, Haggerty CM, Kamireddi AR, Liu Y, Lee J, Persaud D, Gallant JE, Cofrancesco J Jr, Quinn TC, Wilke CO, Ray SC, Siliciano JD, Nettles RE, Siliciano RF: Residual human i mmunodeficiency virus type 1 viremia in some patients on antiretroviral therapy is dominated by a small number of invariant clones rarely found in circulating CD4+ T cells. J Virol 2006, 80:6441-6457.

24. Bailey JR, Brennan TP, O'Connell KA, Siliciano RF, Blankson JN: Evidence of CD8+ T-cell-mediated selective pressure on human immunodeficiency virus type 1 nef in HLA-B*57+ elite suppressors. J Virol 2009, 83:88-97.

25. Salgado M, Brennan TP, O'Connell KA, Bailey JR, Ray SC, Siliciano RF, Blankson JN: Evolution of the HIV-1 nef gene in HLA-B*57 positive elite suppressors. Retrovirology 2010, 7:94.

26. Wei X, Decker JM, Wang S, Hui H, Kappes JC, Wu X, Salazar-Gonzalez JF, Salazar MG, Kilby JM, Saag MS, Komarova NL, Nowak MA, Hahn BH, Kwong PD, Shaw GM: Antibody neutralization and escape by HIV-1. Nature 2003, 422:307-312.

27. Migueles SA, Connors M: Long-term nonprogressive disease among untreated HIV-infected individuals: clinical implications of understanding immune control of HIV. JAMA 2010, 304:194-201.

28. Ferre AL, Hunt PW, Critchfield JW, Young DH, Morris MM, Garcia JC, Pollard RB, Yee HF Jr, Martin JN, Deeks SG, Shacklett BL: Mucosal immune responses to HIV-1 in elite controllers: a potential correlate of immune control. Blood 2009, 113:3978-3989.

29. Kulkarni S, Savan R, Qi Y, Gao X, Yuki Y, Bass SE, Martin MP, Hunt P, Deeks SG, Telenti A, Pereyra F, Goldstein D, Wolinsky S, Walker B, Young HA, Carrington M: Differential microRNA regulation of HLA-C expression and its association with HIV control. Nature 2011, 472:495-498.

30. Shan L, Deng K, Shroff NS, Durand CM, Rabi SA, Yang HC, Zhang H, Margolick JB, Blankson JN, Siliciano RF: Stimulation of HIV-1-specific cytolytic T lymphocytes facilitates elimination of latent viral reservoir after virus reactivation. Immunity 2012, 36:491-501.

doi:10.1186/s12967-014-0335-6

Cite this article as: Moroni et al: Spontaneous control of HIV-1 viremia in a subject with protective HLA-B plus HLA-C alleles and HLA-C associated single nucleotide polymorphisms. Journal of Translational Medicine 2014 12:335.

\section{Submit your next manuscript to BioMed Central and take full advantage of:}

- Convenient online submission

- Thorough peer review

- No space constraints or color figure charges

- Immediate publication on acceptance

- Inclusion in PubMed, CAS, Scopus and Google Scholar

- Research which is freely available for redistribution 